\title{
nano tech 2019
}

佐 藤隆*

\section{1.はじめに}

1 月 30 日から 2 月 1 日までの三日間，東京ビッグサイ トで「nano tech 2019 国際ナノテクノロジー総合展・技術 会議」が行われた。「表面要素技術展」や「Convertech JAPAN 2019」,「新機能性材料展 2019」,「3 次元表面加飾技 術展 2019」なども同時開催され，多くの人で賑わった.

展示規模は 600 社規模，来場者は三日間で 44,000 人ほ どと, 近年と同様の多さであった。展示会の中では, 産学 連携や大学の展示も多かった。また, 各種セミナーが数多 く催されるなど，ビジネスマッチングに留まらず，最新の 開発動向や研究動向まで見渡せるような学際的な展示会と なっていた．数ある展示の中から少数であるが内容を紹介 したい.

\section{2. 小型塗工試験装置}

アカツキ・マキナ陎は，小型塗工試験装置 AT- $01 / 200$ 等を紹介していた. Roll to Roll の乾燥炉付き小型塗工装 置で, 塗工形式に合わせて 3 タイプ（ナイフロールタイプ, スロットダイタイプ, グラビアタイプ）を選べるというこ とである (図 1). High-Low ダンサーによる安定した基材 搬送や低張力搬送も可能ということで，幅広い実験用途に 使えるのではないかと思った.

\section{3．ディスプレイ測定システム}

コニカミノルタジャパン株は，インスツルメントシステ ムズ社の，デイスプレイ測定システム DMS 803 を紹介し ていた（図 2)。さまざまなディスプレイ技術（LCD，有 機 $\mathrm{EL}$ ，電子ペーパー等）の電気光学特性を測定でき，全 自動 6 軸による視野角測定が可能であり, 自動シーケエン ス測定を可能にするソフトウエアも完備しているとのこと である.ささらこの装置は, 数多くの照明装置と温度管理 チャンバーがオプションで装着可能ということで, 反射型 ディスプレイのコントラスト評価や, 様々な温度環境化に おけるデイスプレイの性能評価が可能ということである.

nano tech 2019

* Sato, Takashi

日本ゼオン(株) 精密光学研究所

高岡市二上新 422-1（† 933-0981）

2019.3.13 受理

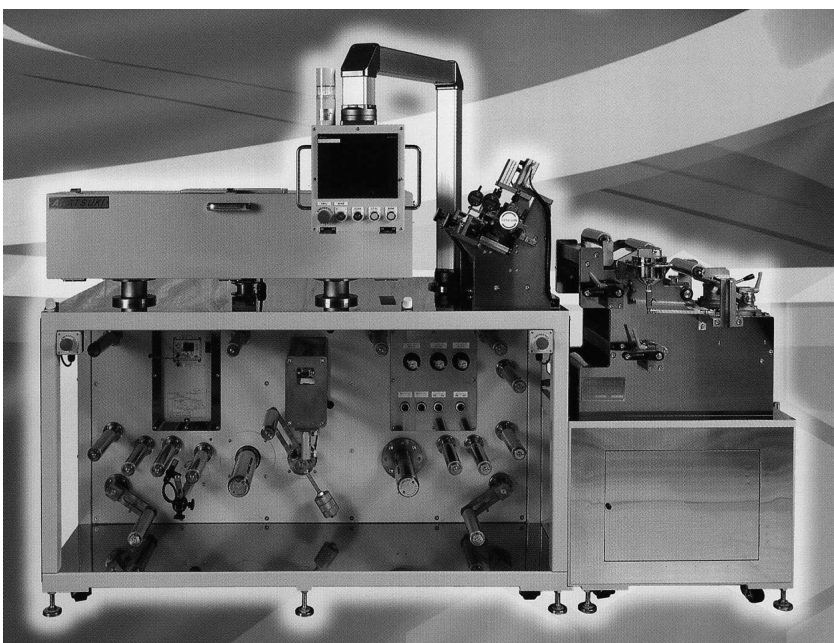

図 1 小型塗工試験装置(アカツキ・マキナ(株)配布資料より)

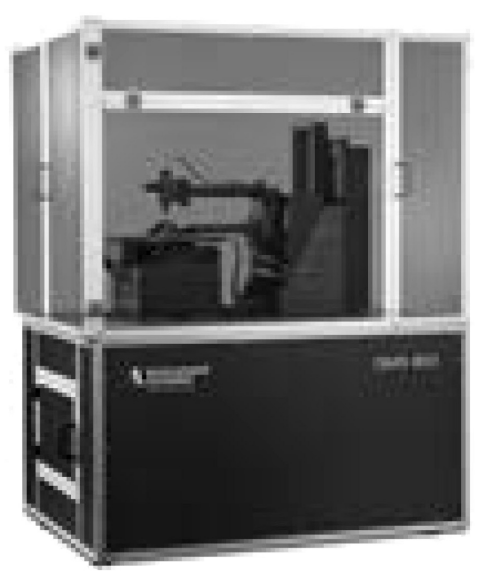

図 2 ディスプレイ測定システム（https://www.konicaminolta.jp/about/release/2014/1027_01_01.html より)

\section{4. $3 \mathrm{D}$ ものづくりセクター}

(地独) 東京都立産業技術研究センターは, 「3 D ものづ くりセクター」を紹介していた。ここでは，3 D-CADを

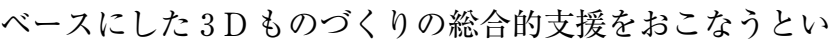
うことで, 試作設計から設計検証, さらに品質評価まで総 合的に支援が受けられるということである．代表的な支援 


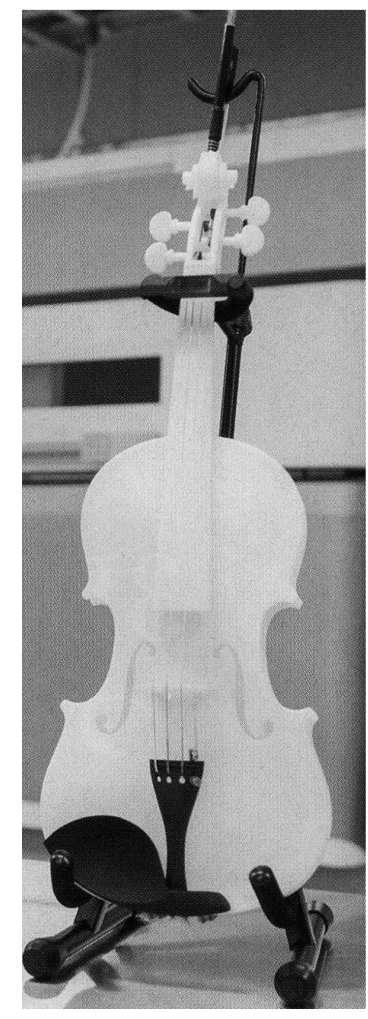

図３３Ｄプリンターで作られたバイオリン （東京都立産業技術研究センター配布資料より）

設備としては，三次元 $\mathrm{CAD} / \mathrm{CAE}$ システム，パターン投 影式三次元デジタイザ, ナイロン粉末造形装置, 金属粉末 造形装置, ワイヤー放電加工, 三次元座標测定器, などを 備えているという.

展示品として，3 D プリンターで作られたバイオリンが 展示されていた（図 3).

\section{5. 超高分解能クライオ SEM}

海洋生命理工学研究開発センターは, 「超高分解能クラ イオ SEM によるバイオミメティクス」の展示を行ってい た. 装置は, Thermo Fisher Scientific 社の Helios G 4 UX で, 生体材料や生体組織, 水系材料の高分解能形態観察を 報告していた（図 4).

\section{6.とやまナノテククラスター}

富山県と (公財) 富山県新世紀産業機構は, 18 のパネル 展示からなる「とやまナノテククラスター」を開催してい た.「ナノテク」と「ものづくり」の融合を謳い,「セルロー スナノファイバー実用化の取り込み」等を展示していた. その中から二つほど紹介する。

一つは, 富山県産業技術研究開発センターの「ナノ粒子 . ナノファイバー生成のための微細化技術」で，株スギノマ シンの液中プラズマチャンバーを応用して，セルロースナ ノファイバー (CNF) の超微細化に成功したとのことで ある.また，有機溶媒中での分散 CNF の開発にも成功し ており，一部はサンプル提供も行っているとのことである (図 5).

もう一つは, 三光合成侏)と富山県立大学との共同研究で $\lceil\mathrm{CNF}$ 配合による高機能 CFRP 複合材料の開発」である.

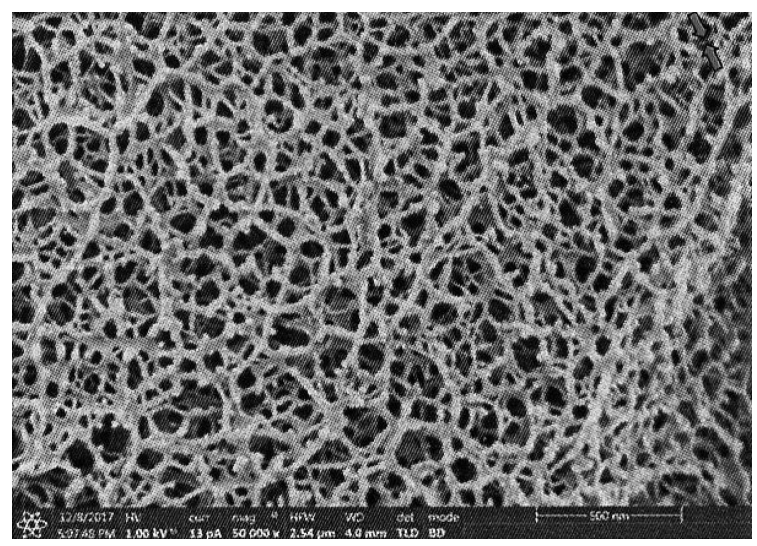

図 4 太さ $8 \mathrm{~nm}$ のゼラチンゲルファイバーの絡み合い網 目構造

(海洋生命理工学研究開発センターの配布資料より)

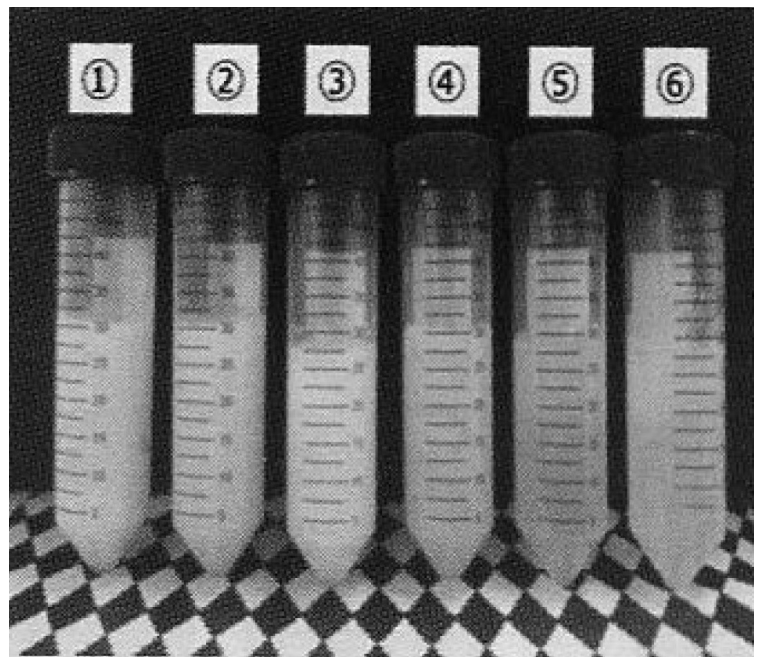

図 5 各種溶媒系での CNF の分散状態 $(2 \mathrm{wt} \%)$; 左から (1)水, (2)エタノール, (3)メチルエルケトン (MEK), (4)ジメチルホルムアルデヒド (DMF), (5)ジメチル スルホキシド (DMSO), (6)トルエン

(とやまナノテククラスターの配布資料より)

CNF として Hydroxypropyl Cellulose（HPC）を用い，架 橋することにより硬化する熱硬化性セルロースを開発し, 炭素繊維シートと複合化することにより，高温においても 弾性率の低下の少ない高性能 CFRP 複合材料を生み出し たとのことである.

\section{7. 機械学習する導電性ポリマー抵抗変化素子}

(国研)科学技術振興機構さきがけから一つ, 表記, ニュー ラルネットワーク回路構築を紹介する. 研究の概要は, 「神 経細胞のように樹状成長し, 空間を自由に配線する有機ポ リマーを使い，神経細胞の情報伝達様式を模したニューラ ルネットワーク機械学習アルゴリズムを用いることで，新 規情報回路を創成する」，ということで，「回路は自ら学習 しながら成長し，脳機能の一部を再現できる素子になる」 とのことである (図 6). なかなか素人には理解が難しい 分野ではあるが，何か画期的な進歩が期待できそうではな いだろうか. 


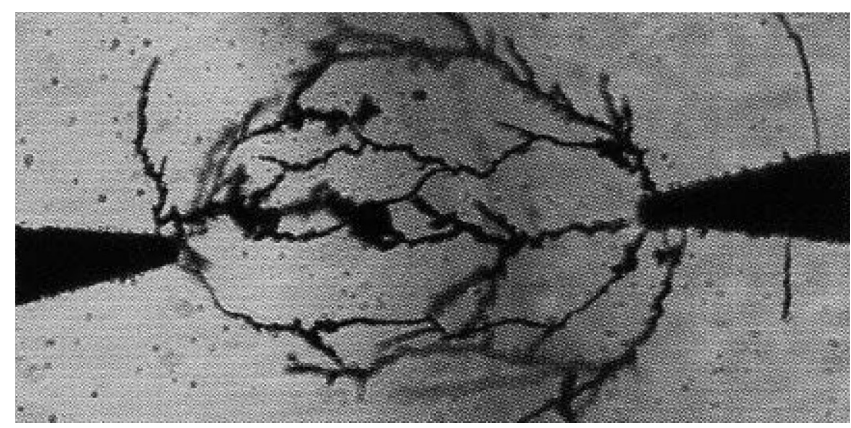

図 6 電極端子間に成長する PEDOT：PPS ポリマー (科学技術振興機構さきがけの配布資料より)

\section{8.まとめ}

ナノテク展は，他の展示会と比べて未来志向である。ま だ研究段階の展示も多く，事業化がどのように進展してい くのか興味深いところである。 そのような中から優れた技 術を見つけ出し予測する先見性が必要ともいえるだろう. 「未来は，現在の中にある」のような言葉を聴いたことが ある．誰の言葉だったかよく覚えていないが，現在の中に も将来大きく花開くようなものがすでにその中に含まれて いる，といったような意味ではなかったかと理解している. 10 年後, 20 年後の技術の発展を予見しながら展示会を回 るのも楽しい.

\section{学位取得者の紹介}

氏 名：五十嵐 敏郎（いがらし としお）

学位取得機関：金沢大学

学 位 名：博士 (工学)

学位取得時期：2019 年 3 月

指 導 教 員：新田 晃平 教授

論 文 題 目: 非破壊劣化診断技術の開発

ーポリエチレンの需要構造の変革を目指してー

所属：金沢大学非常勤講師

連＼cjkstart絡＼cjkstart先：e-mail:yt-igara@canvas.ne.jp

論文要旨:

本論文は，真理探究を目指して研究を深めると同時に， 研究を通して社会に影響を及ぼすことで研究の幅を広げる ことを目的に行った研究について述べる.

第 1 章では, 研究の背景と目的について述べる。ポリエ チレンの研究では, 新規な樹脂グレードの開発など動脈側 の研究は活発に行われているが，非破壊劣化診断に基づく 寿命予測やリサイクルフレークを用いた付加価值の高い製 品開発などの静脈側の研究開発は手薄であった。本研究は, 静脈側の研究の中心課題である非破壊劣化診断技術の開発 を目的とした。また本研究は，リサイクルフレークを用い た製品開発として，発泡層を中間層とする三層構造体 (FSC:Foam Sandwich Construction)の開発を目的とした。

第 2 章では，ポリエチレンの循環サイクルにおける静脈 側の研究で重要な位置を占める非破壊劣化診断技術の開発 について述べる．ポリエチレンが紫外線劣化していく過程 を基礎的に研究する手段としてラマン分光法が有効である ことを見出し, ductile fracture stage での劣化開始メカニ
ズムを明らかにし，その後に続く brittle fracture stage で は結晶度の増加に伴う微細な亀裂の発生が劣化を急激に進 行させていることを明らかにした。また，皮膚科学で開発 された皮膚表面の微小な変化を検知するための手法を応用 して表面摩擦係数の測定を行い，実用的な非破壊劣化診断 技術を開発し，ポリエチレンの紫外線劣化で， brittle fracture stage の後に細片にまで分解される final degradation stage が存在することを明らかにした。

第 3 章では，発泡層を中間層とする FSC の研究と，そ の基礎になる中程度の倍率の発泡研究について述べる.

FSCの研究で，ポリエチレンの種類を選ばずに発泡成形 が可能であること, 発泡剤として OBSH が適しているこ と，4 倍発泡までは成形 Window が広くて曲げ弾性も向上 することを見出した.リサイクルフレークを FSC の中間 発泡層に応用することを可能にする重要な知見である．実 用上重要であるが理論研究が遅れている中程度の倍率の発 泡研究では, 発泡体のセルサイズの分布が広いと発泡セル の崩壊領域での圧縮応力 - 圧縮歪曲線の傾きが大きくなる ことを見出した。

第 4 章では，多品種の製品群を小さなロットサイズで製 造することやデザイン製品の開発に適した回転成形法の普 及活動と究極の多品種小ロット製品の製造法であるアディ ティブマニュファクチャリングについて述べる.

第 5 章では，研究成果の社会実装の可能性について述べ 将来の夢を語る。リサイクルフレークを中間発泡層とした FSC は, ソフトボディカーの外装材, 介護用ロボットの躯 体や地下貯水タンクなど幅広い用途への展開が可能である. 